\title{
Herd Behaviour, Short-Lived Phenomenon: Evidence from Pakistan Stock Exchange
}

\author{
Shaista Jabeen ${ }^{*}$ and Sayyid Salman Rizavi ${ }^{* *}$
}

\begin{abstract}
This research intends to investigate the herd behaviour of investors in Pakistan Stock Exchange (PSX). Previous literature claims that herd behaviour is driven from fundamental information, which causes quick price adjustments to new information and thus leads to efficient markets. However, some researchers have claimed that herd behaviour does not depend upon fundamental information, and hence, leads to price instability. For the purpose of this research, the daily closing stock prices of 528 companies listed in the PSX have been used to calculate the stock returns. The market-wide herd measure, proposed by Chiang and Zheng (2010), has been used to compute the herd behaviour. The data has been investigated for autocorrelation, heteroscedasticity, and stationarity issues. Findings revealed that herding did not exist in PSX, but some sectors did follow this behaviour. This study can help regulators to comprehensively investigate market anomalies leading to smooth market processing.
\end{abstract}

Keywords: Herd behavior, behavioral finance, return dispersions, PSX and stock returns.

JEL Classification: G11, G12, G14

\section{Introduction}

As a general practice, investors carry out either independent decision making for investments in security markets, or follow price leaders or entities with better information or other big players in the market. Moreover, it is believed that people are under the influence of others at the time of decision making. Although such decision making may not be considered rational, it usually exists in stock markets, commodity markets, and foreign exchange markets. Modern statistical tools enable us to test for such behaviour. The above mentioned

\footnotetext{
* PhD Scholar, Hailey College of Commerce and Lecturer, Lahore College for Women University, Pakistan.

** Professor, Hailey College of Commerce and Director General, University of the Punjab, Gujranwala Campus, Pakistan.
} 
discussion leads to the concept of herd behaviour, which is a famous area of behavioural finance. As per academic literature, there are two notable aspects of finance, i.e. traditional finance, and behavioural finance. The former aspect deals with Fama's (1970) Efficient Market Hypothesis $(\mathrm{EMH})$, and later deals with the psyche of market participants. These two aspects can be considered as two extreme views which pertain to the study of investment behaviour.

In the area of behavioural finance, the concept of herding has been used when market participants interact with each other, leading to correlational trade activities (Chiang \& Zheng, 2010). Keynes (1936) has presented the concept of herd behaviour. The main theme of this idea pertains to the investors who do not take into consideration the information that is readily available to them. Instead, these individuals follow the behaviour of the group, even though the group activities might not be based on vital information. Moreover, the investors either follow other knowledgeable investors, because of unavailability of information, or think that other investors possess more concrete and relaiable information. This behaviour was termed as "meme," a psychological demonstration, which means inaccurate views, and principles, transmitted from one investor to another. Van Campenhout and Verhestraeten (2010) further explained that herding depicts a situation where the investors forego their personal information, and follow the crowd, despite knowing that their information is accurate. This may, or may not be a conscious or unconscious effect and can be considered as cognitive bias, or even a planned move. Investors do this to make themselves feel confident, or to minimise their level of uncertainty (Hogg \& Vaughan, 2009). Waweru, Munyoki and Uliana (2008) disclosed that the decision of investors to indulge in buying or selling is significantly influenced by the decision of their peers or group members

Literature reveals that herding seems to be a conjunction of attitudes. These attitudes are triggered when investors follow other individuals, or groups, in securities trading as well as in financial markets. Research shows that there has been positive, as well as negative support for herd behaviour. Some researchers claim that herd behaviour is not dependent upon any fundamental information, and thereby leads to price instability and increases volatility (Venezia, Nashikkar \& Shapira, 2011). Other researchers believe that herding is based on fundamental information causing quick price adjustments to new information, and thus leads to efficient markets (Choi \& Skiba, 2015). It means when new information arrives to the market, stock prices automatically adjust and 
hence herd behaviour too. There are two viewpoints of herding in the security market. One aspect of research has examined how investors do herding around the market by focusing on the market activity data. This viewpoint deals with Cross-Sectional Standard Deviation (CSSD) that is presented by Christie \& Huang (1995). This measure has also been extended by Chang, Cheng and Khorana (2000), and they have termed it as Cross-Sectional Absolute Deviation (CSAD). This herding measure has been applied in several Asian financial markets. Hwang and Salmon (2004) also introduced a proxy for herd behaviour. The second aspect of research is centered up on the herd behaviour that is adopted by institutional investors. Rising momentum of institutions leads to the phenomenon of institutional herding. Liao, Huang and Wu (2011) explained that institutional herd behaviour takes place when institutional investors imitate each other while purchasing and selling securities. Institutional herding was first explained by Lakonishok, Shleifer and Vishny (1992), and it was amended by Sias (2004).

Previous researchers have investigated and observed herd behaviour in both advanced, and developing countries: Chang et al. (2000) in Taiwan and South Korea; Laih and Liau (2013) in Taiwan \& China; El-Shiaty and Badawi (2014) in Egypt; Jlassi and Naoui (2015) in DIJA and S \& P 100 index; Litimi (2017) in certain French sectors; Chong, Liu and Zhu (2016) in China; and Sharma, (2018) in India. However, (Chiang \& Zheng, 2010) explained that herd behavior is a phenomenon which occurrs due to the strong information asymmetry of emerging markets. Limited researches have been conducted on the market-wide herd behaviour in Pakistan, evidence of which has been mentioned in the literature review section of this study. The current study employs Chiang and Zheng (2010) approach to measure herd behavior, which is still not incorporated, and far from embedded in Pakistan's context. This research work intends to achieve the following objectives:

1. To examine the herd behaviour of investors in PSX

2. To find out the prevalence of herd behaviour in all sectors of PSX

\section{Literature Review}

In the financial markets, herd behaviour has different manifestations. These can be categorised into two broader categories: intentional and spurious. It is necessary to differentiate between these two types, but empirically, it is a difficult task due to many factors 
affecting the investment choices of people and firms (Bikhchandani \& Sharma, 2000). Some researchers argued that herding has rational and irrational viewpoints (Hirshleifer \& Teoh, 2009).

Previous researchers have attempted to discover herd behaviour by using the methods of dispersion around market returns. This is especially looked into during the times of considerable variations in security prices. These instances are quite frequent, as herding usually occurs during periods of market stress, when investors forego their personal information and imitate the crowd (Christie \& Huang, 1995) and these considerable variations lead to huge differences in market returns. The correlation in these market returns eventually paves way for marketwide herding. Market-wide herding focuses on the cross-sectional correlation of returns of all the stocks that are traded in the market (Caporale, Philippas \& Economou, 2008).

\subsection{Empirical Evidence of Market-Wide Herding}

Previous researches have showed a mixed trend and prevalence of herd behaviour in stock markets. Some studies demonstrated strong herding effects, while others disclosed its absence.

Chiang and Zheng (2010) highlighted the existence of herd behaviour in advanced stock markets and in Asian markets, but they did not find its traces in the US market. Cakan and Balagyozyan (2014) observed the herding phenomena in the Turkish banking sector between the periods of 2007-2012, through CSSD measure Similarly, Ahsan and Sarkar (2013) could not find evidence of herding in the Dhaka stock market from 2005-2011. However, Teng and Liu (2014) observed the existence of herd behaviour in the Greater Chinese stock markets during the financial crisis of 2008. Other than this, Yao, Ma and He (2014) investigated whether there was a prevalence of herd behaviour in the Chinese A and B share markets. Results revealed that the phenomenon existed especially in the B share market, and was more significant in growth stock, rather than in value stocks.

El-Shiaty and Badawi (2014) observed herd behaviour in the Egyptian stock market by using the CSSD and CSAD measures. Similarly, Ramadan (2015) used the CSAD measure and detected the presence of herd behaviour in Amman's stock market as well. For this purpose, he used the daily data points of the Free Float Share Weighted Index from 2000-2014. Moreover, Zouari, Ghorbel, Ghorbel-Zouari \& Boujelbene 
(2014) studied the concept of herding in the Tunisian market, by using the GARCH model from the period of 2000-2012. His results revealed that there was, indeed, a presence of herd behaviour in the Tunisia Stock Exchange. Other than that, Zheng, Li and Chiang (2017) studied herding in a staggering number of nine Asian markets by using a modified version of the CSAD. Results showed that strong herding effects were observed in the technology and financial sectors, whereas limited effects were found in the utility sectors of these markets. Huang and Wang (2017) studied the factor of fear, and its impact on herd behaviour by using the Volatility Index (VIX), CSSD, and CSAD measures. They concluded that herd behaviour is dependent upon investor's fear and, investors have a tendency to respond to bad news more quickly as compared to the good news. Holmes, Kallinterakis, Ferreira and Pedro (2013) observed that there was a practice of intentional herd behaviour in Portugal's stock market. Similarly, Blasco, Corredor and Ferreruela (2011) detected intentional herding in Spanish markets as well.

Herding phenomenon has been greatly observed in the bullish \& bearish markets. Herd behaviour was existed in Indian National stock market on the S \& P Nifty 50 index between the periods of 1997 to 2008 (Mandal, 2011). A price-based model with the application of the Kalman Filter was used to determine the existence of herding behaviour. It was observed that the phenomenon took place when the market was heading in a positive direction. Similarly, by using the CSAD model, and Hwang's and Salmon's (2004) measures, Demirer, Kutan and Chen (2010) observed that there was a prevalence of herding in Taiwan's bullish market as well.. However, they did not find any support or evidence of herding through the CSSD method. Herd behaviour was observed in Chinese and Indian stock markets as well. The Chinese market exhibited herd behaviour when the market was in decline, while the Indin market showed this behaviour during the bearish market trends (Lao \& Singh, 2011).

Seetharam (2013) explored the pervasiveness of herd behaviour between the period of 1995-2011 in South Africa, and did not observe any signs of it in the bear market. Garg and Jindal (2014) also reported similar results during the days of extreme high and low trading volumes in the stock market. Herd behaviour has also been examined in six Asia Pacific markets during the subprime mortgage crisis (Laih \& Liau, 2013). It was not present in Singapore and Hong Kong. Although it was partially practiced in South Korea and Japan and was completely prevalent in the Stock Exchanges of Taiwan and China. The Karachi Stock Exchange exhibited signs of herding during the bullish and bearish trends as well. It 
was measured through the Ordinary Least Squares (OLS) regression and the Quantile Regression (Malik \& Elahi, 2014).

Chiang, Li and Tan (2010) confirmed the evidence of herding behaviour in the Chinese A share market during its positive and negative trends. They used OLS method and found that there was no support for B shares. However, the quantile regression reported the presence of strong evidence in both types of shares (Luo \& Schinckus, 2015; Sharma, Narayan \& Thuraisamy, 2015) Similarly, Mahmud and Tinic (2015) highlighted that A Shares usually exhibit herding during bearish, and B shares show evidence of this behaviour during the bullish trends.

Rahman, Chowdhury and Sadique (2015) observed herd behaviour in the Saudi stock market as well. While Jlassi and Naoui (2015), showed vigorous proofs of herding in the US stock markets, especially during the bullish periods, and also during the days of high trading volume. Furthermore, a significant connection has been observed between herd behaviour and market sentiment. Chong, Liu and Zhu (2016) highlighted the existence of herd behaviour in the Chinese stock market by using the CSSD model. Hwang, Kim and Sing (2016) examined herd behaviour in the Korean equity market from 2005-2015. Herd behaviour was practiced during the period when the market was under stress, and in the bull market strong herding effects were observed. The herd behaviour during the bullish and bearish trends was observed in Vietnam's stock market during the time span of 2005 to 2015 (Vinh \& Anh, 2016). Similar results were presented by Chiang, Li, Tan and Nelling (2015) in the Pacific-Basin bullish and bearish markets. Their results also showed that herd behaviour was directly linked with the performance of the stock market, and indirectly with market volatility. Chen, Wu and Huang (2017) also used the CSAD measure, and showed that investors engage in herding in China, especially during the rising conditions of the market. They attributed herd behaviour to the irrational expectations of investors. In their study, Mertzanis and Allam (2018) used the CSAD measure, but could not detect the herding effects in the Egyptian stock market, during the bullish and bearish market conditions. This led them to believe that herding was a short-lived aspect. Sharma (2018) also investigated herd behaviour in the Indian stock market. He applied the Generalized Auto Regressive Conditional Heteroscedasticity (GARCH $(1,1)$ in order to remove the heteroscedasticity from the data collected. It was observed that the bullish, bearish, and extreme price movements did not reflect any of the signs of the herding. Moreover, it was revealed that limited herding effects were present during extremely negative trends in the markets. 
Chiang and Zheng's (2010) methodology was also employed by some other authors. For instance, Lindhe (2012) investigated herd behaviour in four Nordic countries. Results revealed that in Finland's stock market, herding behaviour was observed by the investors, even when the market was positive and negative. However, the same is not true in the remaining three countries. Hanafi and Abaoub (2016) noticed that there was prevalence of herd behaviour in the bullish and bearish (before, and during the political \& social crisis period) Tunisian stock market. The research work also focused on the connection between share price and trading volume to identify herding behaviour. Results showed that the herding was present only when the market was going up. Chaffai and Medhioub (2018) revealed the signs of herd behaviour in the Islamic Gulf Cooperation Council stock markets from 2010-2016, both during up and down market conditions.

Limited research has been conducted on herd behaviour in Pakistan, and mixed herding effects prevail in Pakistan's stock market. Javaira and Hassan (2015), and Javed, Zafar, and Hafeez (2013) observed the absence of herd behaviour in Karachi stock market. On the other hand, Malik and Elahi (2014) demonstrated the herding effects in Karachi Stock Exchange in both up and down markets. Herd behaviour was measured through the OLS and quantile regression analysis. Zafar and Hassan (2016) presented the signs of herd behaviour in Pakistan stock market during the bullish, as well as the bearish periods. Shah, Shah and Khan (2017) studied herd behaviour in PSX from 2004-2013 by using the CSSD measure. Qasim, Hussain, Mehboob and Arshad (2019) examined the impact of herd behaviour and the overconfidence bias on decision making of investors in Pakistan, through the quantitative approach.

\section{Data and Methodology}

For the purpose of this study, PSX was referred to as the primary source of data. However, some specific data was collected from the Business Recorder of Pakistan as well. Research work for the study was conducted by taking into consideration 528 companies which had been listed in PSX from June 1998 to June 2018. However, the companies listed after the year 2010 were excluded from the study, in order to maintain the symmetry of the data. This period has been selected, particularily because it gave a holistic view of the data of almost all the listed companies of PSX. It must be noted that PSX consists of 35 sectors, out of which the real estate sector has been excluded for this research (this sector has been not added as it consisted of a single company which was listed after the year 
2010, and hence did not fulfil the definition of the data collection criteria). Sector wise distribution of the companies along with the trading volume of each sector (cumulative figure from the years 1998-2018) have been mentioned in Table 1 . The daily stock prices of the listed companies were collected from PSX in order to calculate the stock returns. The data was analyzed by using the Chiang and Zheng (2010) approach. The stock returns were computed by applying the formula, $\mathrm{LN}\left(\mathrm{P}_{\mathrm{t}} / \mathrm{P}_{\mathrm{t}-1}\right)^{*} 100$. For the purpose of this study, the data has also been tested for autocorrelation, heteroscedasticity, and stationarity issues.

\subsection{Models of Herd Behaviour}

The widely used models of herd behaviour have been explained in this section of the study. Also, as mentioned and justified previously, the current study focuses on the Chiang and Zheng (2010) model.

\subsubsection{Cross-Sectional Standard Deviation (CSSD)}

The work of Christie and Huang (1995) is considered to be one of the pioneer studies which pertain to market-wide herding. Their model focuses on the closeness of returns of individual stock to the returns of market. The model is based on the following workings:

$$
\operatorname{CSSD}=\frac{\sqrt{\sum_{\mathrm{i}=1}^{\mathrm{N}}\left(\mathrm{R}_{\mathrm{i}, \mathrm{t}}-\mathrm{R}_{\mathrm{m}, \mathrm{t}}\right) 2}}{(\mathrm{~N}-1)}
$$

Where, $R_{i, t}=$ stock return of firm $i$ at time $t ; R_{m, t}=$ cross-sectional average return of the $\mathrm{N}$ stocks in the market portfolio at time $\mathrm{t}$; $\mathrm{N}=$ number of stocks in the portfolio.

The presence of herd behaviour is determined through the dummy variable technique. Firstly, the level of dispersion is segregated when the market's return distributions are at an extreme tail level. After this, it is investigated whether it varies from the average level of dispersions, excluding the outermost market returns. The following regression is used to perform these tests:

$$
\operatorname{CSSD}=\alpha+\beta_{1}^{U} D_{t}^{U}+\beta_{2}^{L} D_{t}^{L}+\varepsilon_{t}
$$

Where, $\alpha=$ coefficient that depicts the average dispersion of the sample, and excludes the area covered by two dummy variables; $D_{t}^{L} / D_{t}^{U}=1$, if the 
$\mathrm{R}_{\mathrm{m}}$ on day $\mathrm{t}$ lies in the extreme lower/upper tail of the return distribution, or 0 otherwise.

In the absence of herd behaviour, the dispersion increases from the market, leading to positive coefficients. The negative coefficients exhibit that herd behaviour prevails in the market. Moreover, in the above equation, extreme market movements are defined by making use of the two criteria, i.e. one percent (five percent) upper and lower criteria.

\subsubsection{Cross-Sectional Absolute Deviation (CSAD)}

Although the CSAD model is based on the CSSDs' assumptions, there do exists some differences in it. The CSAD model is more refined as it is able to capture herd behaviour in periods of extreme market returns. This model is based on an absolute deviation of returns. It describes dispersion of returns of individual stock as well as the weighted average market returns. The CSAD model is described with the help of the CAPM model. Presence of herd behaviour leads to the grouping of individual securities returns, especially around the periods of market return. This means that the investors forego personal information, and imitate the information of the market. The model is shown as follows:

$$
\operatorname{CSAD}=\frac{1}{\mathrm{~N}} \sum_{\mathrm{i}=1}^{\mathrm{N}}\left|\mathrm{R}_{\mathrm{i}, \mathrm{t}}-\mathrm{R}_{\mathrm{m}, \mathrm{t}}\right|
$$

Where: $R_{i, t}=$ stock return of firm $i$ at time $t ; R_{m, t}=$ cross-sectional average return of $\mathrm{N}$ stocks in the portfolio at time $\mathrm{t} ; \mathrm{N}=$ number of stocks in the portfolio.

The measure focuses on two parameters of market return, and asserts a non-linear association between individual stock returns, and market returns. This is done in order to effectively show evidence of herd behaviour. In a herd free market, market returns and the individual security returns move in the opposite direction, leading to an increased linear relationship. During the existence of herding, the association between individual security returns, and the corresponding dispersion tend to decrease, or at least increase at a less than proportionate rate as compared to the market return.

The following equation is used to perform the tests:

$$
C S A D=\alpha+\gamma_{1}\left|\mathrm{R}_{\mathrm{m}, \mathrm{t}}\right|+\gamma_{2} R_{m, t}^{2}+\varepsilon
$$


Where, $R_{m, t}=$ market return; $Y_{2}=$ if, significant and negative, infers herd behaviour

CSAD and $R_{m}$ may carry an asymmetric relationship, and herd behaviour can be observed in the bullish and bearish period. This particular test can be applied to the overall market, although it is segregated into two parts, depending upon the direction of the relevant market return

$$
\begin{aligned}
C S A D_{t}^{U P}=\alpha+ & \gamma_{1}^{U P}\left|R_{m, t}^{U P}\right|+\gamma_{2}^{U P}\left(R_{m, t}^{U P}\right)^{2}+\varepsilon_{t} \quad \text { if } \quad R_{m, t}^{U P}>0 \\
C S A D_{t}^{D O W N}= & \alpha+\gamma_{1}^{D O W N}\left|R_{m, t}^{D O W N}\right|+\gamma_{2}^{D O W N}\left(R_{m, t}^{D O W N}\right)^{2}+\varepsilon_{t} \\
& \text { if } R_{m, t}^{D O W N}<0
\end{aligned}
$$

\subsubsection{Chiang and Zheng (2010) Model}

Chiang and Zheng (2010) presented a model that is slightly different from the CSAD:

$\operatorname{CSAD}_{t}=\gamma_{0}+\gamma_{1} R_{m, t}+\gamma_{2}\left|\mathrm{R}_{\mathrm{m}, \mathrm{t}}\right|+\gamma_{3} R_{m, t}^{2}+\varepsilon_{t}$

Where, $C S A D_{t}=$ measure of return dispersion; $R_{m t}=$ value of an equally weighted realized return of all industry indexes on day $\mathrm{t} ;\left|R_{m t}\right|=$ absolute term.

The above equation is different from the one formulated for the CSAD model, in the sense that an additional variable, $R_{m t}$, is included in it. In this way, any variances in the investors' behaviour, in diverse market conditions, can be fully observed. The variable, $\gamma_{2}+\gamma_{1}$, focuses on the association between return dispersion, and market return, when $R_{m, t}$ $>0$. Whereas, $\gamma_{2}-\gamma_{1}$ depicts the same association when $\mathrm{R}_{\mathrm{m}, \mathrm{t}}<0$. CSAD model holds that CAPM asserts a linear association between dispersion in individual security and the market portfolio returns. According to theory, the dispersion in individual asset returns must increase with the increase in the variable, $\left|R_{m, t}\right|$. The investors exhibit herd behaviour by showing a uniform reaction during any large movements or changes in the market prices. So, $R_{m, t}^{2}$ is added, while a significant negative coefficient, $\gamma_{3}$, is consistent with the presence of herd behaviour. 


\subsection{Data Analysis and Interpretation}

The research data is analyzed by using the descriptive statistics, the stationarity test, and the regression analysis. The summary of results, along with interpretation, is explained further on the paper. Moreover, the results of only those sectors have been mentioned which have illustrated the presence of herd behaviour.

Table 1: Sector-wise Distribution of Companies Listed in Pakistan Stock Exchange along with Trading Volume

\begin{tabular}{|c|c|c|c|c|c|c|}
\hline S \# & Sectors & $\begin{array}{c}\text { Number of } \\
\text { Companies } \\
(528)\end{array}$ & $\begin{array}{l}\text { Average } \\
\text { Trading } \\
\text { Volume }\end{array}$ & $\begin{array}{c}\text { Minimum } \\
\text { Trading } \\
\text { Volume }\end{array}$ & $\begin{array}{c}\text { Maximum } \\
\text { Trading } \\
\text { Volume }\end{array}$ & $\begin{array}{c}\text { Standard } \\
\text { Deviation }\end{array}$ \\
\hline 1 & $\begin{array}{l}\text { Automobile } \\
\text { Assembler }\end{array}$ & 12 & 4253755 & 94072 & 17000000 & 4968901 \\
\hline 2 & $\begin{array}{l}\text { Automobile } \\
\text { Parts \& } \\
\text { Accessories }\end{array}$ & 10 & 421770 & 74096 & 1095593 & 291174 \\
\hline 3 & $\begin{array}{l}\text { Cable \& } \\
\text { Electrical Goods }\end{array}$ & 7 & 6736703 & 3190 & 40900000 & 11200000 \\
\hline 4 & Cement & 20 & 27600000 & 317405 & 94500000 & 24700000 \\
\hline 5 & Chemicals & 26 & 9681648 & 3884040 & 25500000 & 5236586 \\
\hline 6 & $\begin{array}{l}\text { Close-End } \\
\text { Mutual Funds }\end{array}$ & 8 & 2449107 & 7554 & 13300000 & 7554 \\
\hline 7 & $\begin{array}{l}\text { Commercial } \\
\text { Banks }\end{array}$ & 20 & 32800000 & 3589408 & 95400000 & 24800000 \\
\hline 8 & Engineering & 12 & 1857321 & 9057 & 13200000 & 3377114 \\
\hline 9 & Fertilizers & 6 & 49600000 & 12800000 & 111000000 & 26400000 \\
\hline 10 & $\begin{array}{l}\text { Food \& } \\
\text { Personal Care } \\
\text { Products }\end{array}$ & 17 & 1245915 & 12779 & 8240481 & 2204149 \\
\hline 11 & $\begin{array}{l}\text { Glass \& } \\
\text { Ceramics }\end{array}$ & 8 & 1548593 & 8547 & 7302221 & 2415468 \\
\hline 12 & Insurance & 29 & 1790132 & 197042 & 3582560 & 744729 \\
\hline 13 & $\begin{array}{l}\text { Investment } \\
\text { Banks }\end{array}$ & 26 & 4754595 & 9702 & 13600000 & 4646118 \\
\hline 14 & Jute & 2 & 13416 & 2365 & 93833 & 21751 \\
\hline 15 & $\begin{array}{l}\text { Leasing } \\
\text { Companies }\end{array}$ & 9 & 276220 & 10115 & 1158352 & 282047 \\
\hline 16 & $\begin{array}{l}\text { Leather \& } \\
\text { Tanneries }\end{array}$ & 5 & 63516 & 2554 & 250479 & 58305 \\
\hline 17 & Miscellaneous & 22 & 2334706 & 101498 & 11000000 & 2711951 \\
\hline 18 & Modarabas & 27 & 478482 & 34644 & 1184225 & 333760 \\
\hline 19 & $\begin{array}{l}\text { Oil \& Gas } \\
\text { Exploration } \\
\text { Companies }\end{array}$ & 4 & 28900000 & 12586 & 106000000 & 36300000 \\
\hline
\end{tabular}




\begin{tabular}{llccccc}
\hline S \# & Sectors & $\begin{array}{c}\text { Number of } \\
\text { Companies } \\
(\mathbf{5 2 8})\end{array}$ & $\begin{array}{c}\text { Average } \\
\text { Trading } \\
\text { Volume }\end{array}$ & $\begin{array}{c}\text { Minimum } \\
\text { Trading } \\
\text { Volume }\end{array}$ & $\begin{array}{c}\text { Maximum } \\
\text { Trading } \\
\text { Volume }\end{array}$ & $\begin{array}{c}\text { Standard } \\
\text { Deviation }\end{array}$ \\
\hline 20 & Oil \& Gas & 6 & 46000000 & 4300332 & 138000000 & 42400000 \\
& $\begin{array}{l}\text { Distribution } \\
\text { Companies }\end{array}$ & & & & & \\
21 & Paper \& Board & 9 & 709835 & 37437 & 2524056 & 721129 \\
22 & Pharmaceuticals & 10 & 453145 & 5245 & 2164663 & 600725 \\
23 & Power & 15 & 33700000 & 4944888 & 100000000 & 29600000 \\
& Generation \& & & & & & \\
& Gas & & & & & \\
& Distribution & & 20900000 & 50767 & 532000000 & 17100000 \\
24 & Refinery & 4 & 375138 & 19136 & 1737133 & 422940 \\
25 & Sugar \& Allied & 33 & & & & \\
& Industries & & & & & \\
26 & Synthetic \& & 11 & 6193403 & 842779 & 20300000 & 5638303 \\
& Rayon & & & & & \\
27 & Technology \& & 8 & 130000000 & 10100000 & 332000000 & 111000000 \\
& Communication & & & & & \\
28 & Textile & 53 & 2928147 & 54092 & 5436573 & 1703821 \\
& Composite & & & & & \\
29 & Textile Spinning & 80 & 392428 & 4206 & 1613837 & 459793 \\
30 & Textile Weaving & 13 & 286411 & 11952 & 1097929 & 324788 \\
31 & Tobacco & 3 & 136949 & 4821 & 440264 & 135125 \\
32 & Transport & 4 & 13100000 & 239095 & 57100000 & 16200000 \\
33 & Vanaspati \& & 6 & 1023664 & 219089 & 19400000 & 4207992 \\
& $\begin{array}{l}\text { Allied } \\
\text { Industries }\end{array}$ & & & & & \\
34 & Woollen & 2 & 170308 & 321 & 1186792 & 289939 \\
\hline
\end{tabular}

Source: Pakistan Stock Exchange, Business Recorder of Pakistan

Table 1 shows the sector wise distribution of companies, as well as the trading volume of these sectors. According to the trading volume, the technology \& communication sector has the highest and the jute sector has the lowest average volume. Moreover, the minimum and maximum values, and the standard deviation have also been mentioned in table 1 .

\section{Table 2: Descriptive Statistics and Stationarity Results of Cross-Sectional Absolute Deviation}

\begin{tabular}{|c|c|c|c|c|c|c|c|}
\hline S \# & Sector & Mean & $\begin{array}{c}\text { Standard } \\
\text { Deviation }\end{array}$ & Minimum & Maximum & CSAD & $\mathrm{Rm}$ \\
\hline & $\begin{array}{l}\text { All Sectors } \\
\text { (Pakistan Stock } \\
\text { Exchange) }\end{array}$ & 2.386 & 1.621 & .0272 & 57.346 & $-38.385^{* * *}$ & $-72.413^{* * *}$ \\
\hline 1 & $\begin{array}{l}\text { Automobile } \\
\text { Assembler }\end{array}$ & 1.932 & 2.008 & .008 & 63.279 & $-58.322^{* * *}$ & $-65.326^{* * *}$ \\
\hline 2 & Automobile Parts & 2.423 & 3.882 & 0 & 122.552 & $-45.065^{* * *}$ & $-74.863^{* * *}$ \\
\hline
\end{tabular}




\begin{tabular}{|c|c|c|c|c|c|c|c|}
\hline S \# & Sector & Mean & $\begin{array}{l}\text { Standard } \\
\text { Deviation }\end{array}$ & Minimum & Maximum & CSAD & $\mathrm{Rm}$ \\
\hline 3 & $\begin{array}{l}\text { and Accessories } \\
\text { Food \& Personal } \\
\text { Care Products }\end{array}$ & 2.145 & 5.643 & .016 & 169.331 & $-51.105^{* * *}$ & $-65.476^{* * *}$ \\
\hline 4 & $\begin{array}{l}\text { Leasing } \\
\text { Companies }\end{array}$ & 2.947 & 3.193 & .003 & 33.600 & $-44.956^{* * *}$ & $-74.678^{* * * *}$ \\
\hline 5 & $\begin{array}{l}\text { Leather \& } \\
\text { Tanneries }\end{array}$ & 2.290 & 4.455 & .0003 & 134.028 & $-48.705^{* * *}$ & $-63.401^{* * *}$ \\
\hline 6 & $\begin{array}{l}\text { Oil \& Gas } \\
\text { Distribution } \\
\text { Companies }\end{array}$ & 1.459 & 2.639 & .002 & 97.297 & $-58.322^{* * *}$ & $-65.326^{* * *}$ \\
\hline 7 & Pharmaceuticals & 1.690 & 3.659 & .014 & 112.344 & $-36.677^{* * *}$ & $-47.550^{* * *}$ \\
\hline 8 & Synthetic \& Rayon & 2.116 & 3.023 & .040 & 76.177 & $-54.084^{* * *}$ & $-77.078^{* * *}$ \\
\hline 9 & Textile Spinning & 3.205 & 3.072 & .105 & 62.190 & $-28.395^{* * *}$ & $-117.25^{* * *}$ \\
\hline 10 & Textile Weaving & 2.860 & 5.237 & .007 & 153.434 & $-55.663^{* * *}$ & $-68.965^{* * *}$ \\
\hline 11 & Woollen & 1.763 & 2.727 & .0008 & 56.570 & $-33.804^{* * *}$ & $-68.179 * * * *$ \\
\hline
\end{tabular}

Source: Pakistan Stock Exchange (Results are computed on the basis of data taken from PSX) Table 2 shows descriptive statistics of Cross-Sectional Absolute Deviation (CSAD) for Pakistan Stock Exchange as well as the sectorial distribution of PSX.

* Statistical significance at the $10 \%$ level

** Statistical significance at the $5 \%$ level

*** Statistical significance at the $1 \%$ level

Table 2 displays the descriptive statistics of PSX, and its sectors. The data ranges from a span of 2469 to 4935 days, and spreads over the period of June 1998 till June 2018. The higher mean values propose significant increase in the market differences that are experienced across sectoral returns. High standard deviation proposes that the stock market, and its sectors, have unusual cross-sectional disparities due to any unforeseen events or tremors in market activity. Moreover, the minimum and maximum, and stationarity values have also been reported in the table. The Augmented Dickey-Fuller (ADF) test has been applied to check the stationarity of the variables identified for the purpose of this study. The null hypothesis of the unit root has been rejected in all the cases. The results of the ADF test show that all the variables, for all the sectors have been stationary at their respective levels. This means that the data has shown consistency over time. This also demonstrates that the mean, variance and the autocorrelation remain stationary, given the time factor involved. 
Table 3: Regression Results

\begin{tabular}{|c|c|c|c|c|c|c|c|}
\hline Sr \# & Sector & $\gamma_{0}$ & $\gamma_{1}$ & $\gamma_{2}$ & $\gamma_{3}$ & $R^{2}$ & $\begin{array}{l}\text { Durbin } \\
\text { Watson }\end{array}$ \\
\hline & All Sectors (PSX) & $\begin{array}{l}2.053^{* * *} \\
(46.26)\end{array}$ & $\begin{array}{l}-.032 \\
(-0.55)\end{array}$ & $\begin{array}{l}.673^{* * *} \\
(7.11)\end{array}$ & $\begin{array}{l}.101^{* * *} \\
(6.83)\end{array}$ & 0.671 & 2.053 \\
\hline 1 & $\begin{array}{l}\text { Automobile } \\
\text { Assembler }\end{array}$ & $\begin{array}{l}.694^{* * *} \\
(7.35)\end{array}$ & $\begin{array}{l}.618^{* * *} \\
(6.97)\end{array}$ & $\begin{array}{l}.322^{* * *} \\
(6.09)\end{array}$ & $\begin{array}{l}-.067^{* * *} \\
(-4.05)\end{array}$ & 0.892 & 2.049 \\
\hline 2 & $\begin{array}{l}\text { Automobile Parts } \\
\text { and Accessories }\end{array}$ & $\begin{array}{l}.510^{* * * *} \\
(10.23)\end{array}$ & $\begin{array}{c}.041 \\
(1.46)\end{array}$ & $\begin{array}{l}1.545^{* * *} \\
(30.91)\end{array}$ & $\begin{array}{l}-.003^{* * *} \\
(-6.25)\end{array}$ & 0.889 & 2.012 \\
\hline 3 & $\begin{array}{l}\text { Food \& Personal } \\
\text { Care Products }\end{array}$ & $\begin{array}{l}.561^{* * *} \\
(8.06)\end{array}$ & $\begin{array}{l}-.013 \\
(-0.35)\end{array}$ & $\begin{array}{l}1.531^{* * *} \\
(22.52)\end{array}$ & $\begin{array}{l}-.002^{* *} \\
(-2.19)\end{array}$ & 0.953 & 2.017 \\
\hline 4 & $\begin{array}{l}\text { Leasing } \\
\text { Companies }\end{array}$ & $\begin{array}{l}.662^{* * *} \\
(20.36)\end{array}$ & $\begin{array}{l}-.012 \\
(-0.86)\end{array}$ & $\begin{array}{l}1.574^{* * *} \\
(47.12)\end{array}$ & $\begin{array}{l}-.007^{* *} \\
(-2.05)\end{array}$ & 0.799 & 2.041 \\
\hline 5 & $\begin{array}{l}\text { Leather \& } \\
\text { Tanneries }\end{array}$ & $\begin{array}{l}.289^{* * *} \\
(4.04)\end{array}$ & $\begin{array}{l}.049 \\
(1.30)\end{array}$ & $\begin{array}{l}1.447^{* * *} \\
(21.59)\end{array}$ & $\begin{array}{c}-.002 * * * \\
(-3.03)\end{array}$ & 0.888 & 2.013 \\
\hline 6 & $\begin{array}{l}\text { Oil \& Gas } \\
\text { Distribution } \\
\text { Companies }\end{array}$ & $\begin{array}{l}.694^{* * *} \\
(7.35)\end{array}$ & $\begin{array}{c}.618 \\
(-6.97)\end{array}$ & $\begin{array}{l}.322^{* * *} \\
(6.09)\end{array}$ & $\begin{array}{l}-.067^{* * *} \\
(-4.05)\end{array}$ & 0.903 & 2.049 \\
\hline 7 & Pharmaceuticals & $\begin{array}{l}.325^{* * * *} \\
(3.87)\end{array}$ & $\begin{array}{l}.045 \\
(1.01)\end{array}$ & $\begin{array}{l}1.362^{* * *} \\
(13.76)\end{array}$ & $\begin{array}{l}-.002^{* *} \\
(-1.72)\end{array}$ & 0.917 & 2.016 \\
\hline 8 & Synthetic \& Rayon & $\begin{array}{l}.483^{* * *} \\
(15.29)\end{array}$ & $\begin{array}{c}.016 \\
(0.78)\end{array}$ & $\begin{array}{l}1.660^{* * *} \\
(42.25)\end{array}$ & $\begin{array}{l}-.008^{* * *} \\
(-9.68)\end{array}$ & 0.884 & 2.009 \\
\hline 9 & Textile Spinning & $\begin{array}{l}1.028^{* * *} \\
(13.05)\end{array}$ & $\begin{array}{l}.060 \\
(1.03)\end{array}$ & $\begin{array}{l}1.943^{* * *} \\
(23.73)\end{array}$ & $\begin{array}{l}-.015^{* * *} \\
(-8.60)\end{array}$ & 0.741 & 2.097 \\
\hline 10 & Textile Weaving & $\begin{array}{l}.584^{* * *} \\
(11.54)\end{array}$ & $\begin{array}{l}.013 \\
(0.53)\end{array}$ & $\begin{array}{l}1.704^{* * *} \\
(37.83)\end{array}$ & $\begin{array}{l}-.004^{* * *} \\
(-7.18)\end{array}$ & 0.946 & 2.016 \\
\hline 11 & Woollen & $\begin{array}{l}-.013 \\
(-0.10)\end{array}$ & $\begin{array}{c}.002 \\
(0.10) \\
\end{array}$ & $\begin{array}{l}1.020^{* * *} \\
(11.66)\end{array}$ & $\begin{array}{l}-.005^{* * *} \\
(-9.77)\end{array}$ & 0.766 & 2.020 \\
\hline
\end{tabular}

Table 3 depicts the daily regression estimates of cross-sectional absolute deviation. Parentheses consist of heteroskedastic t-statistics. Durbin Watson values for autocorrelation are also mentioned.

Table 3 explains the regression results of the PSX, and its respective sectors. Some sectors exhibited autocorrelation and heteroscedasticity issues. The autocorrelation was found to be first order in these sectors, and this problem was removed by applying statistical test. The values of Durbin Watson after removing the autocorrelation, have become closer to the standard values, and are reported in the table. Similarly, the heteroscedasticity has been managed by using the robust standard errors. The Heteroscedastic-t statistics have been presented in parenthesis. Other than this, the adjusted $R^{2}$ explains the changes in CSAD, as described by the market return $\left(R_{m}\right)$, its absolute value $\left(\left|R_{m}\right|\right)$ and the squared value $\left(R^{2} \mathrm{~m}, \mathrm{t}\right)$. While the remaining changes were due to other factors that were held constant in the model. The highest value (0.94) was observed in the textile weaving sector. The value of $\gamma_{1}$ described the unit changes in the cross-sectional absolute deviation, 
caused by one unit change in the market return on an average. The values reached their peak level $(0.07,0.61,0.17$, and 0.95) in PSX, and in some of its sectors (automobile parts \& accessories, automobile assembler, and leasing). The values of $\left|R_{\mathrm{m}}\right|$ were shown through the $\gamma_{2}$ coefficient. Negative values of $\boldsymbol{R}_{\boldsymbol{m}, \boldsymbol{t}}^{2}$ confirmed the presence of herd behaviour. These results imply that herding exists when a negative, and significant relationship exists between the cross sectional absolute deviation, and market returns. This means that the returns of individual firms hold a tendency to form a cluster around the market/industry returns, and as a result, the deviation from the market decreases. As per the results, the PSX did not reveal the existence of herding, but some sectors showed this behaviour nonetheless. In these specific sectors, the values of $\boldsymbol{R}_{\boldsymbol{m}, \boldsymbol{t}}^{\boldsymbol{2}}$ were negative, and significant at different level (1\%, 5\%, 10\%). These revelations lead to the proposition that $\boldsymbol{R}^{2}{ }_{m, t}$ is a measure of extreme market movements, and supports herding in these sectors. Results also provide clarity on the findings that investors forego their own information and follow the crowd in these sectors. Therefore, keeping these results in mind, the asset pricing model did not seem to have support in these sectors. Apart from this, the overall investors in Pakistan Stock Exchange did not show any herding behaviour. It can be inferred that the investors in PSX were more focused on rational decision making processes. However, the question is why herding is practiced in some sectors, but not found not in others. The possible reason for this could be the lack of confidence level of the investors. Another reason could be that these investors imitate the behaviour of other informed or experienced investors in these sectors. And yet, another reason could be that the firms in these sectors have high or low stock returns. Previous researchers argued that herding is a short-lived phenomenon (Christie \& Huang, 1995). The results of this model are also supported by the researchers in different countries, for example, Lindhe (2012), in four Nordic countries, Hanafi and Abaoub (2016) in the Tunisian stock market, and Chaffai and Medhioub (2018) in the Islamic Gulf Cooperation Council stock markets.

\section{Conclusions and Implications}

This study provides significant insights into the market behaviour, as it uses the Chiang and Zheng (2010) approach to measure herd behaviour in PSX, and its associated sectors. PSX did not reveal the existence of herding, but some sectors depicted this behaviour at all possible levels. It can be inferred that the investors in PSX focus more on rational decision making, but, they also follow the information that they get from other investors in some of the sectors that have been included in 
this study. It can also be inferred from the study that herding is an integral component, one which is difficult to eliminate. Some factors which trigger the herding behaviour might include limited knowledge, experience, and homogenous expectations of investors. Moreover, an expectation of uncertainty about the accuracy of the information might also be cause herding behaviour in investors. If the market information is properly conveyed to investors, herding activities can be reduced to a minimum. Besides, investors must consider herding conditions and agendas in order to make rational decisions. On the other hand, managers must aim for financial transparency, as well as detailed and quality controlled financial statements of their respective companies. This transperency in published information can facilitate investors to make better, more informed and confident decisions. Moreover, it will help out decision-making authorities to comprehensively investigate any market anomalies that would eventually lead to smooth market processing. 


\section{References}

Ahsan, A. F. M., \& Sarkar, A. H. (2013). Herding in Dhaka Stock Exchange. Journal of Applied Business and Economics, 14(2), 11-19.

Bikhchandani, S., \& Sharma, S. (2000). Herd Behavior in Financial Markets; A Review. IMF Working Paper No. 00/48. International Monetary Fund.

Blasco, Nativdad, Corredor, P., \& Ferreruela, S. (2011). Detecting intentional herding: what lies beneath intraday data in the Spanish stock market. Journal of the Operational Research Society, 62(6), 1056-1066.

Cakan, E., \& Balagyozyan, A. (2014). Herd behaviour in the Turkish banking sector. Applied Economics Letters, 21(2), 75-79.

Caporale, G. M., Philippas, N., \& Economou, F. (2008). Herding behaviour in extreme market conditions: the case of the Athens Stock Exchange. Economics Bulletin, 7(17), 1-13.

Chaffai, M., \& Medhioub, I. (2018). Herding behavior in Islamic GCC stock market: a daily analysis. International Journal of Islamic and Middle Eastern Finance and Management, 11(2), 182-193

Chang, E. C., Cheng, J. W., \& Khorana, A. (2000). An examination of herd behavior in equity markets: An international perspective. Journal of Banking E Finance, 24(10), 1651-1679.

Chen, Y.-C., Wu, H.-C., \& Huang, J.-J. (2017). Herd Behavior and Rational Expectations: A Test of China's Market Using Quantile Regression. International Journal of Economics and Financial Issues, 7(2), 649-663.

Chiang, Thomas C., Li, J., \& Tan, L. (2010). Empirical investigation of herding behavior in Chinese stock markets: Evidence from quantile regression analysis. Global Finance Journal, 21(1), 111-124.

Chiang, Thomas C., \& Zheng, D. (2010). An empirical analysis of herd behavior in global stock markets. Journal of Banking $\mathcal{E}$ Finance, 34(8), 1911-1921. 
Chiang, Thomas Chinan, Li, J., Tan, L., \& Nelling, E. (2015). Dynamic Herding Behavior in Pacific-Basin Markets: Evidence and Implications. Multinational Finance Journal, 17(3/4), 165-200.

Choi, N., \& Skiba, H. (2015). Institutional herding in international markets. Journal of Banking \& Finance, 55(1), 246-259.

Chong, T. T.-L., Liu, X., \& Zhu, C. (2016). What Explains Herd Behavior in the Chinese Stock Market? Journal of Behavioral Finance, 18(4), 448456.

Christie, W. G., \& Huang, R. D. (1995). Following the Pied Piper: Do Individual Returns Herd around the Market? Financial Analysts Journal, 51(4), 31-37.

Demirer, R., Kutan, A. M., \& Chen, C.-D. (2010). Do investors herd in emerging stock markets?: Evidence from the Taiwanese market. Journal of Economic Behavior E Organization, 76(2), 283-295.

El-Shiaty, D., \& Badawi, A. (2014). Herding behavior in the stock market: An empirical analysis of the Egyptian Exchange, Working Papers 37, The German University in Cairo, Faculty of Management Technology. Available at https://ideas.repec.org/p/guc/ wpaper/37.html

Malkiel, B. G., \& Fama, E. F. (1970). Efficient capital markets: A review of theory and empirical work. The journal of Finance, 25(2), 383-417.

Garg, A., \& Jindal, K. (2014). Herding Behavior in an Emerging Stock Market: Empirical Evidence from India. IUP Journal of Applied Finance, 20(2), 18-36.

Holmes, P., Kallinterakis, V., Ferreira, L., \& Pedro, M. (2013). Herding in a concentrated market: A question of intent. European Financial Management, 19(3), 497-520.

Hirshleifer, D., \& Teoh, S. H. (2009). The psychological attraction approach to accounting and disclosure policy. Contemporary Accounting Research, 26(4), 1067-1090.

Hanafi, C., \& Abaoub, E. (2016). Do Investors Herd in Tunisian Financial Market during Political Crisis Period? Mediterranean Journal of Social Sciences, 7(4), 113. 
Hogg, M. A., \& Vaughan, G. M. (2009). Essentials of social psychology. Pearson Education.

Huang, T.-C., \& Wang, K.-Y. (2017). Investors' Fear and Herding Behavior: Evidence from the Taiwan Stock Market. Emerging Markets Finance and Trade, 53(10), 2259-2278.

Hwang, S., Kim, Y. I., \& Shin, J. (2016). An analysis of herding in the Korean stock market using Network Theory. Jinho, An Analysis of Herding in the Korean Stock Market Using Network Theory (May 26, 2016). Available at SSRN: https://ssrn.com/abstract=2784687 or http://dx.doi.org/10.2139/ssrn.2784687

Hwang, S., \& Salmon, M. (2004). Market stress and herding. Journal of Empirical Finance, 11(4), 585-616.

Javaira, Z., \& Hassan, A. (2015). An examination of herding behavior in Pakistani stock market. International Journal of Emerging Markets, 10(3), 474-490.

Javed, T., Zafar, N., \& Hafeez, B. (2013). Herding Behavior in Karachi Stock Exchange. International Journal of Management Sciences and Business Research, 2(2), 19-28.

Jlassi, M., \& Naoui, K. (2015). Herding behaviour and market dynamic volatility: evidence from the US stock markets. American Journal of Finance and Accounting, 4(1), 70-91.

Keynes, J. M. (1936). The general theory of employment, interest and money. NewYork, NY: Harcourt, Brace and Company.

Laih, Y.-W., \& Liau, Y.-S. (2013). herding behavior during the subprime mortgage crisis: evidence from six Asia-Pacific stock markets. International Journal of Economics and Finance, 5(7), 71.

Lakonishok, J., Shleifer, A., \& Vishny, R. (1992). The impact of institutional trading on stock prices. Journal of Financial Economics, 32(1), 23-43.

Lao, P., \& Singh, H. (2011). Herding behaviour in the Chinese and Indian stock markets. Journal of Asian Economics, 22(6), 495-506. 
Liao, T.-L., Huang, C.-J., \& Wu, C.-Y. (2011). Do fund managers herd to counter investor sentiment? Journal of Business Research, 2(64), 207212.

Lindhe, E. (2012). Herd Behavior in stock markets: a Nordic study. (Master's thesis). Lund University, Lund, Sweden.

Litimi, H. (2017). Herd behavior in the French stock market. Review of Accounting and Finance, 16(4), 497-515.

Luo, Z., \& Schinckus, C. (2015). The influence of the US market on herding behaviour in China. Applied Economics Letters, 22(13), 1055-1058.

Mahmud, S. F., \& Tinic, M. (2018). Herding in Chinese stock markets: A Non-Parametric Approach. Empirical Economics, 55(2), 679-711.

Malik, S. U., \& Elahi, M. A. (2014). Analysis of Herd Behavior Using Quantile Regression: Evidence from Karachi Stock Exchange (KSE). MPRA Paper No. 55322. Available at https://mpra.ub.unimuenchen.de/id/eprint/55322

Mandal, A. (2011). Empirical Study of Herd Behavior: The National Stock Exchange, India. International Journal of Financial Management, 1(3), $1-11$.

Mertzanis, C., \& Allam, N. (2018). Political Instability and Herding Behaviour: Evidence from Egypt's Stock Market. Journal of Emerging Market Finance, 17(1), 29-59.

Qasim, M., Hussain, R., Mehboob, I., \& Arshad, M. (2019). Impact of herding behavior and overconfidence bias on investors' decisionmaking in Pakistan. Accounting, 5(2), 81-90.

Rahman, M. A., Chowdhury, S. S. H., \& Shibley Sadique, M. (2015). Herding where retail investors dominate trading: The case of Saudi Arabia. The Quarterly Review of Economics and Finance, 57(August), 46-60.

Ramadan, I. Z. (2015). Cross-sectional absolute deviation approach for testing the herd behavior theory: The case of the ASE Index. International Journal of Economics and Finance, 7(3), 188-193. 
Seetharam, Y. (2013). An analysis of herding behavior during market cycles in South Africa. Journal of Economics and Behavioral Studies, 5(2), 89-98.

Shah, M. U. D., Shah, A., \& Khan, S. U. (2017). Herding behavior in the Pakistan stock exchange: Some new insights. Research in International Business and Finance, 42(December), 865-873.

Sharma, K. (2018). Herding in the Banking Sector of Indian Stock Market: An Empirical Study of Banknifty. Journal of Commerce $\mathcal{E}$ Accounting Research, 7(2), 34-43.

Sharma, S. S., Narayan, P., \& Thuraisamy, K. (2015). Time-Varying Herding Behavior, Global Financial Crisis, and the Chinese Stock Market. Review of Pacific Basin Financial Markets and Policies, 18(02), 31.

Sias, R. W. (2004). Institutional herding. Review of Financial Studies, 17(1), 165-206.

Teng, Y.-P., \& Liu, Y. A. (2014). The study of herding behavior among the Greater China stock markets during financial crisis. Journal of Interdisciplinary Mathematics, 17(2), 163-197.

Van Campenhout, G., \& Verhestraeten, J. F. (2010). Herding behavior among financial analysts: A literature review. Working Paper 2010/39, Hogeschool-Universiteit Brussel, Faculteit Economie en Management.

Venezia, I., Nashikkar, A., \& Shapira, Z. (2011). Firm specific and macro herding by professional and amateur investors and their effects on market volatility. Journal of Banking \& Finance, 35(7), 1599-1609.

Vinh, V. X., \& Anh, P. D. B. (2016). Herd Behavior in Emerging Equity Markets: Evidence from Vietnam. Asian Journal of Law and Economics, 7(3), 369-383.

Waweru, N. M., Munyoki, E., \& Uliana, E. (2008). The effects of behavioural factors in investment decision-making: a survey of institutional investors operating at the Nairobi Stock Exchange. International Journal of Business and Emerging Markets, 1(1), 24-41. 
Yao, J., Ma, C., \& He, W. P. (2014). Investor herding behaviour of Chinese stock market. International Review of Economics $\mathcal{E}$ Finance, 29(January), 12-29.

Zafar, N., \& Hassan, A. (2016). An Empirical Investigation of Herding: Case of Karachi Stock Exchange. Pakistan Journal of Life and Social Sciences, 14(2), 60-69.

Zheng, D., Li, H., \& Chiang, T. C. (2017). Herding within industries: Evidence from Asian stock markets. International Review of Economics E Finance, 51(1), 487-509.

Zouari, D., Ghorbel, A., Ghorbel-Zouari, S., \& Boujelbene, Y. (2014). Herding Behavior Contagion in Tunisian Financial System During the Revolution Period. The IUP Journal of Bank Management, 13(4), 20-36. 